\title{
IS VILLAGE-LEVEL MICROFINANCE BENEFICIAL AT THE COMMUNITY, ENTERPRISE AND HOUSEHOLD LEVELS? A CASE STUDY FROM INDONESIA
}

\author{
Ahmad Rifai * \\ Department of Agribusiness, Riau University \\ Koi-Nyen Wong \\ Department of Economics and Finance, Sunway University \\ Soo-Khoon Goh \\ Centre for Policy Research \& international Studies, Universiti Sains Malaysia
}

\begin{abstract}
The local governments of the Riau Province of Indonesia had been given the mandate to use UED-SP as a microfinance programme to serve the financial needs of the rural poor, to promote rural economic activities and to create employment opportunities. Despite the village-level microfinance programme was able to accomplish rural outreach with financial sustainability (Rifai et al., 2019), there is limited evidence to validate its real impact on the rural MFI participants at three different levels of village development. The findings reveal that microloans appear to have positive impacts on the microfinance participants at the community level, at the level of micro-enterprise and at the household level. The rural MFIs should be targeting this village segment of the rural poor, while the local governments should provide the support to warrant deeper outreach.
\end{abstract}

Keywords: Microfinance, microfinance institutions, UED-SP MFIs, poverty, impact assessment, Indonesia

Received: 29 March 2020

Accepted: 27 September 2021

https://doi.org/10.33736/ijbs.4319.2021

\section{INTRODUCTION}

Usaha Ekonomi Desa - Simpan Pinjam (UED-SP) Microfinance Institutions (MFIs) or UED-SP MFIs, which was introduced by the Village Empowerment Programme, were established in the Riau Province in 2005 with the objective to generate income, to promote economic activities and to create employment in the rural communities so that the wellbeing of the locals could be improved. The rollout of the rural microfinance in the province then was the consequent of the high poverty rate of $14.7 \%$ in the rural areas when the local governments were delegated with poverty reduction responsibility within their regional development programmes. The local government was allocated with the initial capital of IDR500 million for the execution of UED-SP

- Corresponding author: Agribusiness Department, Riau University, Kampus Binawidya, Jln. Bina Krida, Pekanbaru, Riau, Indonesia, 28293; Tel: +62761-63271; Email: ahmad.rifai@lecturer.unri.ac.id 
MFIs. Hence, this results in Rokan Hulu being the rural area in the province with complete implementation of rural MFIs as a poverty reduction tool. Since the launch of UED-SP MFIs in Rokan Hulu in 2005, the impact assessment of the MFIs on their rural clients has neither been performed internally nor externally. Therefore, the impact of the UED-SP MFIs on poverty reduction have not been clearly known, except for a study by Yuniati (2014), who examined whether the UED-SP MFIs' loans would improve the household income in local community in Rokan Hulu. Their findings did not support the hypothesis that the presence of UED-SP MFIs could raise the income level of the villagers. The study also revealed that the micro-loans had been inappropriately utilised by the rural borrowers.

The microfinance sector continues to grow (see Microfinance Barometer, 2018), and yet the social and economic impact assessment of microfinance is still limited. Since UED-SP MFIs are largely driven by the outreach mission rather than the financial performance, they are seen as an important tool for rural poverty reduction and rural development in the Riau Province, where the local governments had been delegated with the responsibility to serve the financial needs of the rural poor. However, carrying out outreach mission is a costly activity, which might compromise its financial performance (especially for UED-SP MFIs that are not only not-for-profit but also with limited years of experience in micro-lending). It is noteworthy that the success of serving the poor by the rural MFIs was attributed to one of the guiding principles that they must develop financial products and services to generate revenue in order to cover their operational costs to support their financial sustainability. A recent study on the outreach and financial sustainability of UED-SP MFIs by Rifai et al. (2019) revealed that the rural MFIs were able to accomplish the social mission (i.e. to broaden and deepen the outreach activities) without compromising the financial sustainability, advocating the microfinance operations were run using the hybrid approach i.e. the outreach and financial sustainability are complementary rather than competitive.

Little has been done to assess the social and economic impacts of MFIs on the poor borrowers, who have limited access to credit. Therefore, the aim of this study is to ascertain whether UED-SP MFIs are beneficial to the rural communities (in terms of job creation), the micro-enterprises (in terms of rural microenterprise development such as business expansion and cost reduction etc.), and the households (in terms of raising incomes, savings as well as improving the wellbeing such as education and health). Moreover, the findings that reveal sound microfinance practices resulting in potential social and economic impacts will also be beneficial to the donors, governments and other institutions, which are committed to promote the future growth and development of the microfinance sector.

\section{LITERATURE REVIEW}

Having captivated the world over the past few decades, alleviating rural poverty with microfinance is often regarded as an important development agenda for both state and local governments. With the provision of MFIs targeting on the rural and the disadvantaged communities, microfinance is seen as a prospective development strategy that potentially could relieve poverty of the rural poor. Khalily (2004) classified poverty alleviation as an end outcome of MFIs, which comes after the intermediate outcomes such as the social and economic impacts accruing to households, microenterprises and community through the extension of microcredit by MFIs to their clients (such as households and micro-enterprises) as shown in Figure 1. The immediate outcomes (impacts) could 
occur at three levels, namely, household, enterprise and community (see Hulme, 1997; Hulme, 2000; Matul \& Tsilikounas, 2004). The roles of MFIs on each level will be discussed in subsections 2.1 and 2.2 .

Figure 1: The intermediate and end outcomes of MFI intervention.

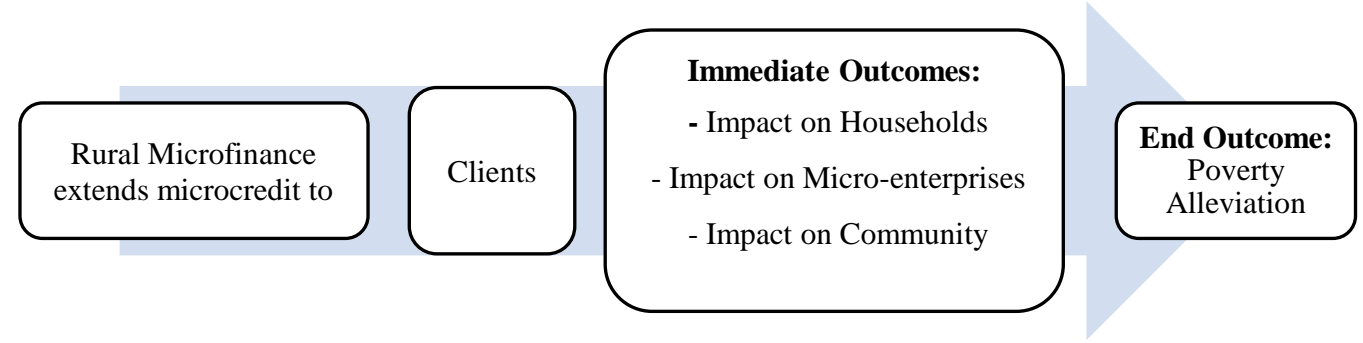

\subsection{The Role of MFIs on Households}

According to Ledgerwood (1999), MFIs could be used as a tool for financial and social intermediation that could help to make a difference in the lives of low-income people. Besides incomes and savings, the poor households could afford to invest in their children's education as well as better medical services with the intervention of microfinance (Littlefield et al., 2003; Khalily, 2004). As the microfinance sector continues to grow, MFIs tend to struggle financially owing to high operating costs, declining interest rates and inability to attract savings (see Microfinance Barometer, 2018). Furthermore, "only 1-2\% of all MFIs in the world (i.e., some 150 organisations) are financially sustainable. The remaining group of MFIs (70\% of all organisations) consist of smaller, start-up organisations, which are still far from being financially sustainable and are, therefore, (heavily) dependent on subsidies" (Hermes \& Lensink, 2011, p. 878). In effect, small loans catered for large-scale poor borrowers tend to increase transaction cost due to loan screening, monitoring and contract enforcement (Navajas et al., 2000). Hence, microfinance serving the populations at the bottom of the pyramid could be costly (Adam \& Von Pischke, 1992), and may result in MFIs compromising on reaching out to the rural poor given the gravity of high operating costs. As such, trade-offs may exist between the impact and the financial sustainability (Zeller \& Meyer, 2002).

With these potential trade-offs in mind, an assessment of microfinance impact on poverty is necessary so that the donor agencies/non-profit organisations could appraise whether the donations/funds that have been raised to support the strategic mission of a microfinance programme is well invested. If a microfinance programme is found to be beneficial in relieving poverty through the improvement in social and economic development of the poor at the village or regional level at viable financial cost, there is a prima facie case of future funding for the microfinance movement. Undeniably, the ideal business model of microfinance is an MFI that could serve the social mission with an impact while being sustainable financially. However, microfinance programmes that are financially sustainable do not guarantee real impacts, which are contingent on how MFIs reach out to the target populations (Khandker, 1998), how the outreach and financial sustainability missions of MFIs are executed symbiotically, the microfinance programmes' design and organisational efficiencies (Karlan \& Goldberg, 2007), and the level of 
village development of MFIs' clients (Rifai et al., 2019). The empirical evidence on the impact of microfinance on the poor is mixed. Studies supporting the proposition that microloans that could improve people's lives (e.g., income levels, access to health and education of children, and housing etc) in Bangladesh, Ghana, Kenya, Malaysia and Pakistan can be found in Khandker and Samad (2014), Boateng et al. (2015), Okibo and Makanga (2014), Mamun et al. (2012) and Mahmood et al. (2016).

\subsection{The Role of MFIs on Micro-enterprises and Community}

MFIs not only can serve as a channel for microlending to the poor to facilitate consumption smoothing at the household level, but also are a direct source of fund for start-up and expansion of rural microenterprises and income-generating activities, which in turn would lead to new job creation (see Chowdhdury \& Mosley, 2004; Brau et al., 2009). So, the chain effect of job creation at the enterprise level as a result of MFI intervention could contribute to an increase in employment at the community level (see Hulme, 1997; Matul \& Tsilikounas, 2004). On the other hand, empirical studies by Mahajan (2005), Pollin and Feffer (2007), Banerjee et al. (2015), Chowdhury (2009), and Bateman and Chang (2012) showed contrary results. Chowdhury (2009) remarked that microcredit per se was not the only factor that potentially could generate income or output as other complementary factors such as borrowers' entrepreneurial skills are crucial in making microcredit more productive. This finding is supported by Banerjee et al. (2015), who found that most poor people did not have the basic education or experience to understand and manage a business. Mahajan (2005) argued that microcredit was a necessary but not a sufficient condition for microenterprise promotion. It was found that not only maintaining a vibrant domestic market is desirable for microenterprise promotion so that the supply of decent wage-paying jobs in their local economies could be increased, but also having access to decent roads and affordable means are instrumental in reaching broader customers by microenterprises (Pollin \& Feffer, 2007). Therefore, Bateman and Chang (2012) found that the microfinance model, which tends to have an adverse impact on poverty reduction, can be caused by (a) ignoring the crucial role of the scale of economies, (b) ignoring the fallacy of composition, (c) helping to de-industrialise and infantilise the local economy, (d) failing to connect with the rest of the enterprise sector, (e) the preprogrammed to precipitate a sub-prime-style over-supply of microfinance and (f) ignoring the crucial importance of solidarity and local community ownership and control.

\section{METHODOLOGY}

\subsection{Study Design and Setting}

Alleviating poverty and developing rural entrepreneurship are an important development agenda for the Riau Province of Indonesia. Rural areas like Rokan Hulu, which is one of the twelve regencies in the province, is not exempted. Rokan Hulu not only had the highest poverty incidents compared to other regencies but also there was total microfinance coverage for all its villages. In this regard, Rokan Hulu provides an important case to examine the impact of UED-SP MFIs on the wellbeing of the poor as well as the rural entrepreneurship. Hence, the impact analysis of the intervention by UED-SP MFIs at the household, enterprise and community level is timely, and is of particular interest to the local governments of the Riau Province that provided the initial capital to fund the MFI operations, the managers of the UED-SP MFI programme, the rural households, 
the rural micro-enterprises and the rural community that are the potential beneficiaries from this MFI programme. Figure 2 depicts that the financially sustainable UED-SP MFIs could reach out to their clients to generate positive impacts at three different levels such as household (in terms of modifying their income, savings, children's education and access to healthcare), micro-enterprise (in terms of enterprise development) and community (in terms of job opportunities).

Figure 2: Impact of MFI outreach at household, micro-enterprise and community levels

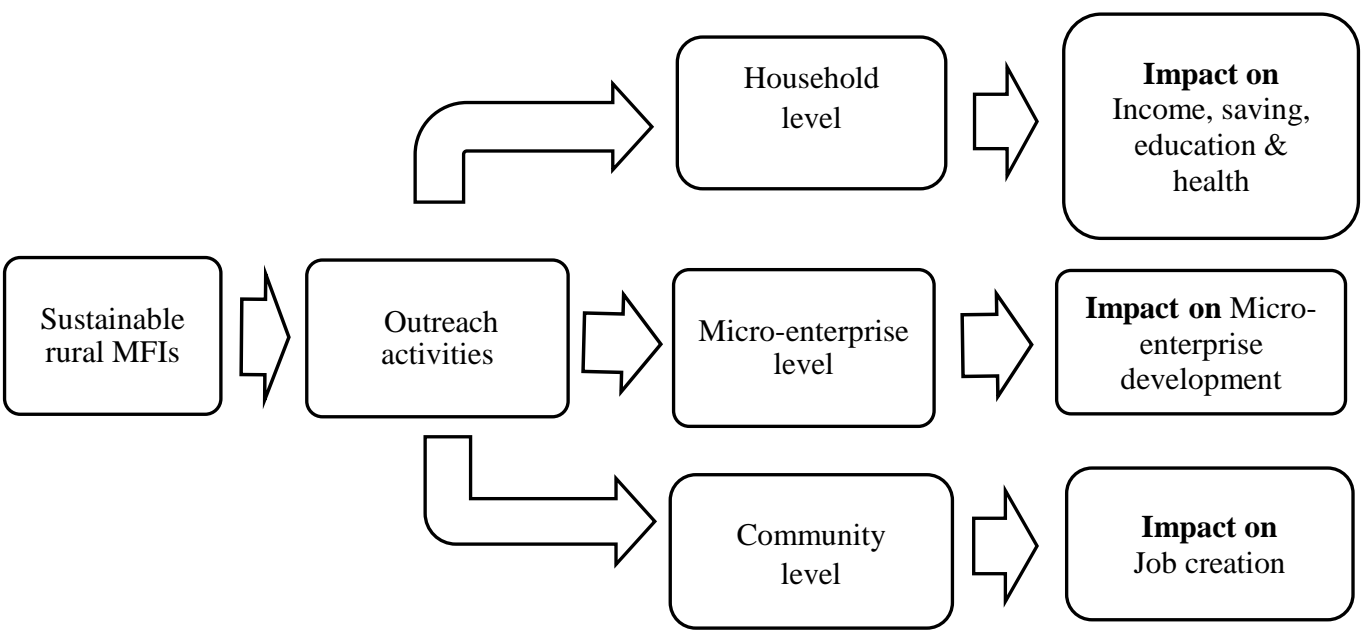

The sample frame of the study is the households and enterprises that received loans from the UEDSP MFIs in the villages, and the survey covers 164 beneficiaries of UED-SP MFIs due to the officials of UED-SP MFIs did not have a detailed household data and the micro-enterprise development of the borrowers had never been evaluated. In addition, the long-distance ranges of the villages made it infeasible to visit and interview of all the officials of the UED-SP MFIs to get more data and information on the practices of the UED-SP MFIs. Accordingly, this approach sees the impact of UED-SP MFIs financial services especially where credit as a service could be instrumental in improving the livelihood opportunities for the borrowers through a combination of increasing their incomes and improving their wellbeing. The extent to which the borrowers have benefited from the loans that were provided by the UED-SP MFIs can be assessed in terms of the observed changes (improved or not improved) in the social and economic dimensions in Subsection 3.3.

\subsection{Study population and sampling}

The assessment impact of UED-SP MFIs on the rural poor and microenterprises was examined in three different levels of village development, namely, the developed, the developing and the underdeveloped. The classification of the village development level, which is based on basic infrastructure such as access to electricity and clean water, health-care services, education and transportation, is derived from the Technical Guidance of the Identification of the remote villages, 
the under-developed villages and small islands (Panduan teknis identifikasi desa terpencil, desa tertinggal dan pulau-pulau kecil) published by the Ministry of Public Works of Indonesia. The sample villages were selected by using the random sampling technique, while the purposive sampling technique was used to select sample households of the UED-SP MFIs' borrowers. As such, eight villages were selected (i.e. $5 \%$ of 153 villages) representing the three village development levels. Hence, the distribution of selected villages by the level of village development is 3 villages from 59 developed villages, 4 villages from 71 developing villages, and 1 village from 23 under-developed villages. Regarding the household sampling, 5\% of the borrowers of the UEDSP MFIs was selected from each level of village development, amounting to 164 households in total, and the distribution of respondents by the level of village development is as follows: 80 sample borrowers (i.e. $48.78 \%$ of the grand total) from the developed villages, 73 sample borrowers (i.e. $44.51 \%$ of the grand total) from the developing villages, and 11 sample borrowers (i.e. $6.71 \%$ of the grand total) from the under-developed villages. The data were collected from the primary sources using questionnaires obtained from the borrowers of UED-SP MFIs.

\subsection{Data Analysis}

A Chi-square test was conducted to determine whether the MFI intervention had any bearing on the wellbeing of village development. Whereas the Wilcoxon Rank Sum test was applied to investigate whether the income of the household borrowers improves after receiving loans from UED-SP MFIs. This nonparametric test is used to test the null hypothesis that the quality of life of the borrowers does not differ before and after receiving loans from the UED-SP MFIs. Differences are calculated for the before and after conditions. A significance level of up to the 0.05 level (5\%) was chosen to determine a significant relationship between the categorical variables.

\section{RESULTS AND DISCUSSION}

\subsection{A Profile of Borrowers from UED-SP MFIs in Rokan Hulu}

The data were collected from the primary sources using questionnaires obtained from the borrowers of UED-SP MFIs in Rokan Hulu. A profile of the borrowers can be found in Table 1. Overall, the sample borrowers were in the productive age category with an average age of 40.85 years old despite the sample borrowers from the under-developed villages were older than their counterparts from both the developed and developing villages. In terms of gender and marital status for all the villages, the male and married borrowers were more prominent with $73 \%$ and $92 \%$ respectively. The average size of a borrower's family for this case study was 3.63 persons. However, the majority did not attend university even with $55.49 \%$ had completed senior high school. Moreover, $45.45 \%$ of the sample borrowers from under-developed villages did not even complete their primary education. With respect to the frequency of loans obtained by a typical borrower for all villages, $64 \%$ of the borrowers received a loan from UED-SP MFIs once, while the remaining $36 \%$ of the borrowers had taken a loan two times or more. In fact, the percentage of borrowers who took a loan for at least two times was greater for developed village (37.50\%) than developing village (35.62\%) and under-developed village (27.27\%). Meanwhile, the term of loans is 18 months. Based on the loan requirements, a borrower can only apply for a second loan if the previous loan has been paid for. Every qualified borrower has an equal opportunity to apply for a credit from any of the UED-SP MFIs. 
Table 1. The profile of the UED-SP MFIs borrowers

\begin{tabular}{|c|c|c|c|c|}
\hline \multirow[b]{2}{*}{ Description } & \multicolumn{3}{|c|}{ Village Development Level } & \multirow[b]{2}{*}{$\begin{array}{l}\text { All Villages } \\
(\mathbf{n}=164)\end{array}$} \\
\hline & $\begin{array}{l}\text { Developed } \\
\text { Village } \\
(\mathbf{n}=\mathbf{8 0})\end{array}$ & $\begin{array}{c}\text { Developing } \\
\text { Village } \\
(n=73)\end{array}$ & $\begin{array}{c}\text { Under- } \\
\text { developed } \\
\text { Village }(\mathbf{n}=\mathbf{1 1})\end{array}$ & \\
\hline Average age (years) & 41.33 & 38.90 & 50.27 & 40.85 \\
\hline \multicolumn{5}{|l|}{ Gender } \\
\hline Male & $60(75.00)$ & $50(68.49)$ & $10(90.91)$ & $120(73.17)$ \\
\hline Female & $20(25.00)$ & $23(31.51)$ & $1(9.09)$ & $44(26.83)$ \\
\hline \multicolumn{5}{|l|}{ Marital status } \\
\hline Single & $1(1.25)$ & $4(5.48)$ & $0(0)$ & $5(3.05)$ \\
\hline Married & $78(97.50)$ & $66(90.41)$ & $7(63.64)$ & $151(92.07)$ \\
\hline Widower & $1(1.25)$ & $2(2.74)$ & $4(36.36)$ & $7(4.27)$ \\
\hline Divorced & $0(0)$ & $1(1.37)$ & $0(0)$ & $1(0.61)$ \\
\hline \multicolumn{5}{|l|}{ Maximum level of formal education } \\
\hline Less than primary school (6 years) & $1(1.25)$ & $1(1.37)$ & $5(45.45)$ & $7(4.27)$ \\
\hline Completed primary school (6 years) & $12(15.00)$ & $7(9.59)$ & $1(9.09)$ & $20(12.20)$ \\
\hline Attended secondary school & $17(21.25)$ & $18(24.66)$ & $4(36.36)$ & $39(23.78)$ \\
\hline Completed secondary school & $45(56.25)$ & $45(61.64)$ & $1(9.09)$ & $91(55.49)$ \\
\hline Attended college or university & $5(6.25)$ & $1(1.37)$ & $0(0)$ & $6(3.66)$ \\
\hline Average of household members (persons) & 3.66 & 3.63 & 3.45 & 3.63 \\
\hline \multicolumn{5}{|l|}{ Frequency of loan to UED-SP MFIs } \\
\hline One times & $50(62.50)$ & $47(64.38)$ & $8(72.73)$ & $105(64.02)$ \\
\hline Two times and more & $30(37.50)$ & $26(35.62)$ & $3(27.27)$ & $59(35.98)$ \\
\hline
\end{tabular}

Note: Values in parentheses are percentages of household borrowers by level of village development and in all villages.

\subsection{Rural MFI Impact on Rural Community}

An interesting aspect of this part of the survey was the opinions about the MFI impact on rural job opportunities as an impact of UED-SP MFIs on the rural community. Table 2 shows that about 11 per cent of the responses from all villages perceived that the microloans were able to create rural job opportunities for their business undertakings. The average number of workers involved in their microenterprises increased from 1.08 (before microloan undertaking) to 1.19 (after microloan undertaking). Whilst the $p$ value from the Chi-square test confirms that the micro-enterprises from both the developed and developing villages have higher propensity to hire workers than their counterparts from the underdeveloped villages. This suggests that with microloans extended to micro-enterprises, they are more inclined to expand micro-enterprise activities (as a consequence of the dynamic change in terms of the production process, market opportunities and profit motive of business, in both developed and developing villages) leading to job opportunities in the rural areas. 
Table 2. The impact of loans on the rural job opportunities

\begin{tabular}{|c|c|c|c|c|c|c|}
\hline Description & $\begin{array}{c}\text { Developed } \\
\text { Village }(n=80)\end{array}$ & $\begin{array}{c}\text { Developing } \\
\text { Village } \\
(\mathbf{n}=73)\end{array}$ & $\begin{array}{c}\text { Under- } \\
\text { developed } \\
\text { Village }(n=11)\end{array}$ & $\begin{array}{l}\text { All Villages } \\
(n=164)\end{array}$ & $\chi^{2}$ & $p$ \\
\hline \multicolumn{7}{|c|}{ Hiring more workers in micro-enterprises after loans } \\
\hline Yes & $16(20.00)$ & $3(4.11)$ & $0(0.00)$ & $19(11.59)$ & \multirow{2}{*}{10.954} & \multirow{2}{*}{0.004} \\
\hline No & $64(80.00)$ & $70(95.89)$ & $11(100.00)$ & $145(88.41)$ & & \\
\hline \multicolumn{7}{|c|}{ Average number of workers } \\
\hline Before loan & 1.19 & 1.00 & 1.00 & 1.09 & & \\
\hline After loan & 1.34 & 1.04 & 1.00 & 1.18 & & \\
\hline
\end{tabular}

\subsection{Rural MFI Impact on Rural Micro-enterprises}

One of the missions of the UED-SP MFIs is to generate more rural business activities. Hence, the impact assessment of the rural MFIs on the rural micro-enterprise development was performed in the sphere of: (1) expansion of business activities, (2) cost reduction, (3) new products, (4) quality improvement/value adding, and (5) selling products in new market/location. Table 3 shows that more than two-thirds of the responses from the developed and developing villages perceived that loans received from the rural MFIs were instrumental in expanding their business activities as opposed to less than one-third of the responses from the under-developed villages believed that they could only grow their micro-enterprises with the microloans. On further analysis using Chisquare test (see the $p$ values in first panel of Table 3), there is a significant association between the impact of the loans on business expansion of the micro-enterprises and the level of village development after received loan from UED-SP MFIs. It is implying micro-entrepreneurs from both the developed and developing villages had the edge over their counterparts in terms of business expansion attributable to better education that encourage micro-enterprise management and better rural infrastructure to support their business activities. It was indicated more than one-third of the borrowers from the developed and developing villages were of the opinion that microloans were a cheaper source of credit that could lower the operating cost of their micro-enterprises, whereas less than one-third of them felt that microloans could only reduce the operating cost through bulk purchase (refer to the third and second panels of Table 3 respectively). Nevertheless, none of the borrowers from the under-developed villages agreed that microloans could reduce the operating cost because they believed that the small loans were inadequate to reap the benefit of bulk purchase.

Table 3 also shows that more than $96 \%$ of the respondents from all villages were able to sell their products in new markets (refer to the sixth panel of the results). When it came to adding new products (refer to the fourth panel of Table 3 ) and adding value to existing products (refer to the fifth panel of Table 3), only $31 \%$ and $26 \%$ of the borrowers from all the villages respectively agreeing that this was an important impact of microloans. However, the $p$ values of the Chi square test results reveal that there is no a significant association between the level of village development and the ability of the micro-entrepreneurs to add new products as well as add value to the existing products. Similarly, Onyina and Turnell (2013) found that the provision of financial services by the Sinapi Aba Trust (SAT) as a major microfinance institution in Ghana had improved the welfare of its beneficiaries in terms of employment creation to generate regular income. 
Table 3. The impact of loans on the borrowers' microenterprise activities after loans from UED-SP MFIs

\begin{tabular}{|c|c|c|c|c|c|c|}
\hline Description & $\begin{array}{c}\text { Developed } \\
\text { Village }(\mathbf{n}=\mathbf{8 0})\end{array}$ & $\begin{array}{c}\text { Developing } \\
\text { Village } \\
(n=73)\end{array}$ & $\begin{array}{c}\text { Under- } \\
\text { developed } \\
\text { Village }(n=11)\end{array}$ & $\begin{array}{l}\text { All Villages } \\
\quad(n=164)\end{array}$ & $\chi^{2}$ & $p$ \\
\hline \multicolumn{7}{|c|}{ Expanding the size of micro-enterprises activity } \\
\hline Yes & $61(76.25)$ & $54(73.97)$ & $3(27.27)$ & $118(71.95)$ & \multirow{2}{*}{11.761} & \multirow{2}{*}{0.003} \\
\hline No & $19(23.75)$ & $19(26.03)$ & $8(72.73)$ & $46(28.05)$ & & \\
\hline \multicolumn{7}{|c|}{ Reducing costs by buying production inputs in greater volume or at wholesale price } \\
\hline Yes & $11(13.75)$ & $2(2.74)$ & $0(0.00)$ & $13(7.93)$ & \multirow{2}{*}{7.355} & \multirow{2}{*}{0.025} \\
\hline No & $69(86.25)$ & $71(97.26)$ & $11(100.00)$ & $151(92.07)$ & & \\
\hline \multicolumn{7}{|c|}{ Reducing costs due to cheaper source of credit } \\
\hline Yes & $23(28.75)$ & $36(49.32)$ & $0(0.00)$ & $59(35.98)$ & \multirow{2}{*}{13.634} & \multirow{2}{*}{0.001} \\
\hline No & $57(71.25)$ & $37(50.68)$ & $11(100.00)$ & $105(64.02)$ & & \\
\hline \multicolumn{7}{|c|}{ Adding new products of micro-enterprises } \\
\hline Yes & $30(37.50)$ & $17(23.29)$ & $4(36.36)$ & $51(31.10)$ & \multirow{2}{*}{3.751} & \multirow{2}{*}{0.153} \\
\hline No & $50(62.50)$ & $56(76.71)$ & $7(63.64)$ & $113(68.90)$ & & \\
\hline \multicolumn{7}{|c|}{ Improving the quality or desirability of products/adding value } \\
\hline Yes & $25(31.25)$ & $17(23.29)$ & $2(18.18)$ & $44(26.83)$ & \multirow{2}{*}{1.682} & \multirow{2}{*}{0.431} \\
\hline No & $55(68.75)$ & $56(76.71)$ & $9(81.82)$ & $120(73.17)$ & & \\
\hline \multicolumn{7}{|c|}{ Selling products in new markets/locations } \\
\hline Yes & $77(96.25)$ & $71(97.26)$ & $11(100.00)$ & $159(96.95)$ & \multirow[b]{2}{*}{0.503} & \multirow{2}{*}{0.778} \\
\hline No & $3(3.75)$ & $2(2.74)$ & $0(0.00)$ & $5(3.05)$ & & \\
\hline
\end{tabular}

\subsection{MFI Impact on the Households}

The increase of household income of the borrowers might lead to allowing the households to meet their needs, such as food consumption, children's education and health care. Hence, their welfare increase. The possible impact of the UED-SP MFIs on the improvement of the welfare of the borrowers was analysed by way of: 1) impact on household's income and savings, 2) impact on household's food consumption and 3) impact on children's education and medical services.

\section{Impact on household's income and saving}

The findings (see Table 4) also indicate that the rural MFIs play an influential role in improving the economic wellbeing of the villagers. Before microloan undertaking, the average household income and per capita income were IDR 2.88 million per month and IDR 0.85 million per month, respectively. After microloan undertaking, they both increased to IDR 4.09 million and IDR 1.2 million per month, respectively. As the household income increased, the per capita income also increased. The per capita income increased from IDR 0.85 million per month before receiving loans to IDR 1.2 million per month after receiving loans from UED-SP MFIs. This result may be explained by the fact that the borrower's generated higher returns after obtained additional capital from UED-SP MFIs to improve their micro-enterprises through create new business activities, expanding micro-enterprises and improving the production processes. This result is in agreement with the previous study that was conducted by Chirkos (2014) who found that the majority of the clients of the microfinance in Ethiopia could increase their incomes. 
microloans (see Table 6). Nonetheless, reaching out to the borrowers from the under-developed villages would not change their saving patterns, which remained at $9 \%$. On average, the responses show that after microloan undertaking, savings increased from IDR 90.11 million to IDR 97.35 million or all villages. The borrowers from both the developed and developing villages have the ability to improve their savings and liquid assets after receiving the loans from the UED-SP MFIs. As seen in Table 6, the $p$ values of the Chi-square test results reveal there is a significant association between the level of village development and the borrowers' ownership of savings or liquid assets before receiving the loans from the UED-SP MFIs. The liquid asset is the stock of all kinds of liquid financial assets that can be sold at any time when it is necessary. This result indicates that the villagers from both the developed and developing villages had the ability to save money or to invest in liquid assets as a result of MFI intervention that had a positive impact on household income. This evidence corroborates the study by Chirkos (2014) that the clients of MFIs could cope with their unexpected expenses using savings.

Table 6. Impact of the UED-SP on borrowers' savings

\begin{tabular}{|c|c|c|c|c|c|c|}
\hline Saving or Liquid Assets & $\begin{array}{c}\text { Developed } \\
\text { Village }(\mathbf{n}=\mathbf{8 0})\end{array}$ & $\begin{array}{c}\text { Developing } \\
\text { Village } \\
(\mathbf{n}=73) \\
\end{array}$ & $\begin{array}{c}\text { Under- } \\
\text { developed } \\
\text { Village }(n=11) \\
\end{array}$ & $\begin{array}{l}\text { All Villages } \\
\quad(n=164)\end{array}$ & $\chi^{2}$ & $p$ \\
\hline \multicolumn{7}{|l|}{$\overline{\text { Before loan }}$} \\
\hline $\begin{array}{l}\text { Do not have savings or liquid } \\
\text { assets }\end{array}$ & $42(52.50)$ & $37(50.68)$ & $10(90.91)$ & $89(54.27)$ & \multirow[t]{2}{*}{6.429} & \multirow[t]{2}{*}{0.04} \\
\hline Have savings or liquid assets & $38(47.50)$ & $36(49.32)$ & $1(9.09)$ & $75(45.73)$ & & \\
\hline \multicolumn{7}{|l|}{ After loan } \\
\hline $\begin{array}{l}\text { Do not have savings or liquid } \\
\text { assets }\end{array}$ & $39(48.75)$ & $30(41.10)$ & $10(90.91)$ & 79 (48.17) & \multirow{2}{*}{9.522} & \multirow[t]{2}{*}{0.009} \\
\hline Have savings or liquid assets & $41(51.25)$ & $43(58.90)$ & $1(9.09)$ & $85(51.83)$ & & \\
\hline \multicolumn{7}{|c|}{ Average savings or liquid assets (IDR Million) } \\
\hline Before Loan & 93.64 & 88.79 & 3.50 & 90.11 & & \\
\hline After Loan & 103.61 & 93.52 & 5.00 & 97.35 & & \\
\hline
\end{tabular}

\section{Impact on household's food consumptions}

In view of whether there was an improvement in villagers' dietary after receiving the microloans, the majority i.e. $92.68 \%$ reported that they were better off in terms of higher meal frequency per day (see Table 7). However, among the three levels of village development the rural people from both the developed and developing villages still experienced higher meal frequency per day relative to their counterparts from the under-developed villages. With regard to daily dietary intake condition, $54.88 \%$ of the respondents said that their dietary improved after receiving the microloans, while $44.51 \%$ were relatively neutral on this question. The other investigation on food consumption improvement of the borrowers shows that the borrowers' household from the developing villages have had better daily diet condition after receiving loans from the UED-SP MFIs compared to both developed and under-developed villages. The $p$ values of the Chi-square test results imply that there is a significant association between the level of village development and the daily meal frequency of the borrowers after receiving loan from the UED-SP MFIs. Indeed, the loans provided by the UED-SP MFIs played a positive role in improving the household income 
of the borrowers in the rural areas that eventually improve the ability of the borrowers to meet their daily diet conditions.

Table 7. Daily meal frequency and dietary condition improvement with microloan undertaking

\begin{tabular}{|c|c|c|c|c|c|c|}
\hline \multirow[b]{2}{*}{ Description } & \multicolumn{3}{|c|}{ Level of Village Development } & \multirow[b]{2}{*}{$\begin{array}{c}\text { All Villages } \\
(\mathbf{n}=164)\end{array}$} & \multirow[b]{2}{*}{$\chi^{2}$} & \multirow[b]{2}{*}{$p$} \\
\hline & $\begin{array}{c}\text { Developed } \\
\text { Village } \\
(\mathbf{n}=\mathbf{8 0})\end{array}$ & $\begin{array}{c}\text { Developin } \\
\text { g Village } \\
(\mathrm{n}=73)\end{array}$ & $\begin{array}{c}\text { Under- } \\
\text { developed } \\
\text { Village } \\
(n=11)\end{array}$ & & & \\
\hline \multicolumn{7}{|c|}{ a. Daily meal frequency after loans } \\
\hline One a day or no meal & $2(2.50)$ & $3(4.11)$ & $7(63.64)$ & $12(7.32)$ & \multirow{2}{*}{55.293} & \multirow{2}{*}{0.000} \\
\hline More than twice a day & $78(97.50)$ & $70(95.89)$ & $4(36.36)$ & $152(92.68)$ & & \\
\hline \multicolumn{7}{|c|}{ b. Daily dietary condition after loans } \\
\hline Worsened & $0(0)$ & $0(0)$ & $1(9.09)$ & $1(0.61)$ & \multirow{3}{*}{29.599} & \multirow{3}{*}{0.000} \\
\hline Stayed the same & $44(55.00)$ & $21(28.77)$ & $8(72.73)$ & $73(44.51)$ & & \\
\hline Improved & $36(45.00)$ & $52(71.23)$ & $2(18.18)$ & $90(54.88)$ & & \\
\hline
\end{tabular}

Note: $\mathrm{N}=164$; values in parentheses are the percentages of household borrowers by level of village development and in all villages.

\section{Impact on children's education}

The first panel of Table 8 shows that the majority of the village borrowers, irrespective of the level of village development, were of the opinion that the microloans could increase their affordability of school fees as well as education level. $66.46 \%$ of all the responses indicated that the rural MFIs were instrumental in increasing their propensity to afford their children's education. The expectations about the highest level of education after microloan undertaking, $54.27 \%$ of all the respondents said that the rural MFIs could act as a catalyst for the pursuit of their children's tertiary education, with the exception for the under-developed villages (see the second and the third panels of Table 8).

Table 8. Ability of the borrowers to improving their children's education

\begin{tabular}{|c|c|c|c|c|c|c|}
\hline \multirow[t]{2}{*}{ Description } & \multicolumn{3}{|c|}{ "Level of Village Development } & \multirow[b]{2}{*}{$\begin{array}{c}\text { All Villages } \\
(\mathbf{n}=164)\end{array}$} & \multirow[b]{2}{*}{$\chi^{2}$} & \multirow[b]{2}{*}{$p$} \\
\hline & $\begin{array}{c}\text { Developed } \\
\text { Village } \\
(\mathbf{n}=\mathbf{8 0})\end{array}$ & $\begin{array}{c}\text { Developing } \\
\text { Village } \\
(\mathbf{n}=73)\end{array}$ & $\begin{array}{c}\text { Under- } \\
\text { developed } \\
\text { Village } \\
(n=11)\end{array}$ & & & \\
\hline \multicolumn{7}{|c|}{ a. Ability of the borrowers to pay schooling fee their children compared to last school year after loan } \\
\hline Decrease $(\%)$ & $3(3.75)$ & $2(2.74)$ & $0(0.00)$ & $5(3.05)$ & \multirow{3}{*}{4.457} & \multirow{3}{*}{0.348} \\
\hline Stay the same $(\%)$ & $30(37.50)$ & $17(23.29)$ & $3(27.27)$ & $50(30.49)$ & & \\
\hline Increase $(\%)$ & $47(58.75)$ & $54(73.97)$ & $8(72.73)$ & $109(66.46)$ & & \\
\hline \multicolumn{7}{|c|}{ b. Expectation maximum level of schooling of their children before loan } \\
\hline $\begin{array}{l}\text { Attended primary school or } \\
\text { unexpected }(\%)\end{array}$ & $56(70.00)$ & $47(64.38)$ & $1(9.09)$ & $104(63.41)$ & \multirow{3}{*}{8.900} & \multirow{3}{*}{0.064} \\
\hline $\begin{array}{l}\text { Attended secondary school } \\
(\%)\end{array}$ & $3(3.75)$ & $8(10.96)$ & $0(0.00)$ & $11(6.71)$ & & \\
\hline $\begin{array}{l}\text { Attended college or } \\
\text { university }(\%)\end{array}$ & $21(26.25)$ & $18(24.66)$ & $10(90.91)$ & $49(29.88)$ & & \\
\hline
\end{tabular}




\begin{tabular}{|c|c|c|c|c|c|c|}
\hline \multirow[t]{2}{*}{ Description } & \multicolumn{3}{|c|}{ Level of Village Development } & \multirow[b]{2}{*}{$\begin{array}{l}\text { All Villages } \\
\quad(n=164)\end{array}$} & \multirow[b]{2}{*}{$\chi^{2}$} & \multirow[b]{2}{*}{$p$} \\
\hline & $\begin{array}{l}\text { Developed } \\
\text { Village } \\
(\mathbf{n}=\mathbf{8 0})\end{array}$ & $\begin{array}{l}\text { Developing } \\
\text { Village } \\
(\mathbf{n}=73)\end{array}$ & $\begin{array}{c}\text { Under- } \\
\text { developed } \\
\text { Village } \\
(n=11) \\
\end{array}$ & & & \\
\hline \multicolumn{7}{|c|}{ c. Expectation maximum level of schooling of their children after loan } \\
\hline $\begin{array}{l}\text { Attended primary school or } \\
\text { unexpected }(\%)\end{array}$ & $50(62.50)$ & $23(31.51)$ & $1(9.09)$ & $74(45.12)$ & & \multirow{3}{*}{0.040} \\
\hline Attended secondary school (\%) & $1(1.25)$ & $0(0.00)$ & $0(0.00)$ & $1(0.61)$ & 10.048 & \\
\hline $\begin{array}{l}\text { Attended college or university } \\
(\%)\end{array}$ & $29(36.25)$ & $50(68.49)$ & $10(90.91)$ & $89(54.27)$ & & \\
\hline
\end{tabular}

Note: $\mathrm{N}=164$; value in parentheses is the percentage of household borrowers by level of village development and in all villages.

The $p$ values of the Chi-square test results indicate that there is a significant association between the level of village development and the expectation maximum level of schooling of their children after receiving loan from the UED-SP MFIs. These findings are consistent with previous studies that microfinance not only could generate positive impact on the level of children's expectations of schooling (Hussein \& Hussain, 2003; Noreen et al., 2011) but also could increase the expenditure on children's education (Onyina \& Turnell, 2013; Chirkos, 2014). The results also confirm the positive role played by microfinance in terms of better access to education facilities in rural areas (Mazumder \& Lu, 2015) as well as raising the education levels (Boateng et al., 2015).

\section{Impact on medical services}

Opinions about the impact of rural MFIs on the accessibility to and affordability of medical facilities) were also critical. Table 9 (refer to panels a and b) shows that the most popular healthcare facilities were the rural healthcare centres irrespective of before and after microloan undertaking attributable to the fact that they were a community-based healthcare that was built in the subdistricts' capital. The $p$ values of the Chi-square test results suggest that there is no significant association between the level of village development and the type of healthcare facilities used when sick before and after receiving loan from the UED-SP MFIs.

Table 9. Affordability and accessibility of medical services

\begin{tabular}{|c|c|c|c|c|c|c|}
\hline \multirow[b]{2}{*}{ Description } & \multicolumn{3}{|c|}{ Level of Village Development } & \multirow[b]{2}{*}{$\begin{array}{c}\text { All } \\
\text { Villages } \\
(n=164)\end{array}$} & \multirow[b]{2}{*}{$\chi^{2}$} & \multirow[b]{2}{*}{$p$} \\
\hline & $\begin{array}{c}\text { Developed } \\
\text { Village } \\
(\mathbf{n}=\mathbf{8 0})\end{array}$ & $\begin{array}{c}\text { Developing } \\
\text { Village } \\
(\mathbf{n}=73)\end{array}$ & $\begin{array}{c}\text { Under- } \\
\text { developed } \\
\text { Village } \\
(\mathbf{n}=11) \\
\end{array}$ & & & \\
\hline \multicolumn{7}{|c|}{ a. Type of healthcare facilities used when sick before loan } \\
\hline Rural polyclinic & $10(12.50)$ & $6(8.22)$ & $6(54.55)$ & $22(13.41)$ & & \\
\hline Rural healthcare centre & $60(75.00)$ & $63(86.30)$ & $5(45.45)$ & $128(78.05)$ & 20.831 & 0.000 \\
\hline Hospital & $10(12.50)$ & $4(5.48)$ & $0(0.00)$ & $14(8.54)$ & & \\
\hline \multicolumn{7}{|c|}{ b. Type of healthcare facilities used when sick after loan } \\
\hline Rural polyclinic & $11(13.75)$ & $8(10.96)$ & $7(63.64)$ & $26(15.85)$ & & \\
\hline Rural healthcare centre & $58(72.50)$ & $61(83.56)$ & $4(36.36)$ & $123(75.00)$ & 24.071 & 0.000 \\
\hline Hospital & $11(13.75)$ & $4(5.48)$ & $0(0.00)$ & $15(9.15)$ & & \\
\hline
\end{tabular}




\begin{tabular}{|c|c|c|c|c|c|c|}
\hline \multirow[b]{2}{*}{ Description } & \multicolumn{3}{|c|}{ Level of Village Development } & \multirow[b]{2}{*}{$\begin{array}{c}\text { All } \\
\text { Villages } \\
(n=164)\end{array}$} & \multirow[b]{2}{*}{$\chi^{2}$} & \multirow[b]{2}{*}{$p$} \\
\hline & $\begin{array}{c}\text { Developed } \\
\text { Village } \\
(\mathbf{n}=\mathbf{8 0})\end{array}$ & $\begin{array}{c}\text { Developing } \\
\text { Village } \\
(n=73)\end{array}$ & $\begin{array}{c}\text { Under- } \\
\text { developed } \\
\text { Village } \\
(\mathbf{n}=11) \\
\end{array}$ & & & \\
\hline \multicolumn{7}{|c|}{$\begin{array}{l}\text { c. Ability to pay basic healthcare cost in rural healthcare centre and/or rural polyclinic before loans (basic } \\
\text { healthcare facility) }\end{array}$} \\
\hline Unable & $1(1,25)$ & $1(1,37)$ & $0(0,00)$ & $2(1,22)$ & \multirow{2}{*}{0.150} & \multirow{2}{*}{0.928} \\
\hline Able & $79(98.75)$ & $72(98.63)$ & $11(100.00)$ & $162(98.78)$ & & \\
\hline \multicolumn{7}{|c|}{ d. Ability to pay basic healthcare cost in hospital after loans (secondary healthcare facility) } \\
\hline Unable & $20(25,00)$ & $19(26,03)$ & $8(72,72)$ & $47(28,66)$ & \multirow{2}{*}{11.220} & \multirow{2}{*}{0.004} \\
\hline Able & $60(75.00)$ & $54(73.97)$ & $3(27.27)$ & $117(71.34)$ & & \\
\hline
\end{tabular}

When asked about their affordability of basic and secondary healthcare facilities, $98.78 \%$ and $71.34 \%$ of all the respondents agreed that microloans could increase their ability to pay for healthcare costs in rural healthcare centres and/or rural polyclinics, and hospitals respectively (see panels $\mathrm{c}$ and $\mathrm{d}$ of Table 9). On the contrary, the people from the under-developed villages believed that they could not afford the higher cost of healthcare in hospital as many as the dwellers from both the developed and developing villages (refer to panel d of Table 9). The $p$ values of the Chisquare test results imply that there is a significant association between the level of village development and the ability of the villager to pay basic cost in hospital after receiving loan from the UED-SP MFIs. Overall, these findings support those found by Chirkos (2014) that the MFIs could increase the capacity of their clients to pay for their healthcare, and tended to have positive impact on the rural healthcare (Mazumder \& Lu, 2015).

\section{CONCLUSION}

The poor in the Riau Province of Indonesia are concentrated in the rural areas rather in urban areas. The local governments had been given the mandate to use UED-SP as a microfinance programme not only to serve the financial needs of the rural poor but also to promote rural economic activities and to create employment opportunities. Despite the village-level microfinance programme was able to accomplish rural outreach with financial sustainability (see Rifai et al., 2019), there is limited evidence to validate the real impact on the rural MFI participants at three levels of village development i.e., developed village, developing village and under-developed village. This paper aims to ascertain the extent to which the impact of UED-SP MFIs on the rural communities, the rural micro-enterprises and the rural households at each mentioned level of village development in the province, which is still facing challenges in reducing poverty.

At the community level, there was a positive microfinance impact on job creation, particularly for developed and developing villages. Much of the job creation was the positive repercussions associated with the business expansion experienced by the rural microenterprises. While at the enterprise level, microloans appeared to be beneficial to the microenterprise development in the sphere of business expansion activities, reduction in operating costs and bulk purchase, especially for the micro-entrepreneurs from both the developed and developing villages. The positive impact of microfinance on microenterprise development apparently was attributable to higher level of education acquired by the micro-entrepreneurs and the better infrastructure that is in place for the developed and the developing villages. At the household level, the access to microcredit tended to 
raise the average income and average saving, which in turn, could lead to food consumption (i.e. higher meal frequency per day), especially for dwellers from both the developed and the developing villages. When it comes to medical services (in terms of affordability of and accessibility to medical facilities) and children's education (in terms of affordability and education level), there is evidence that microloans did seem to have a positive impact on education and health except the dwellers from the underdeveloped villages. In this regard, in order to make a difference in rural people's lives, UED-SP MFIs should target at the borrowers from the underdeveloped villages, and the local governments should continue to provide full support to rural MFIs to ensure deeper outreach, exclusively in the underdeveloped villages.

\section{LIMITATIONS OF THE STUDY}

Despite the findings from the impact assessment study are beneficial to the stakeholders like the local governments of the Riau Province (that provided the initial capital to the rural MFIs to promote rural development and to alleviate rural poverty), UED-SP MFIs (that are directly responsible to accomplish the social mission while keeping their MFI operations afloat financially), and the rural community including the poor households and micro-enterprises (who are the potential beneficiaries of the MFI programme), they are certain limitations in the survey data representation. For instance, the number of people involved in the interviews at the data collection stage was limited owing to the villages were located in remote areas and they were very far apart from each other. In addition, the tight timescale made it even more challenging to interview as many people as possible given the fact that the villages were isolated.

\section{REFERENCES}

Adam, D. W., \& Pischke, J. D. V. (1992). Microenterprise credit programs: Déja vu? World Development, 20(10), 1463-1470.

Banerjee, A., Duflo, E., Glennerster, R., \& Kinnan, C. (2015). The Miracle of Microfinance? Evidence from a Randomized Evaluation. American Economic Journal: Applied Economics, $7(1), 22-53$.

Bateman, M., \& Chang, H. (2012). Microfinance and the Illusion of Development: From Hubris to Nemesis in Thirty Years. World Economic Review, 1, 13-36.

Boateng, G. O., Boateng, A. A., \& Bampoe, H. S. (2015). Microfinance and Poverty Reduction in Ghana: Evidence from Policy Beneficiaries. Review of Business and Finance Studies, 6(1), 99-108.

Brau, J. C., Hiatt, S., \& Woodworth, W. (2009). Evaluating Impacts of Microfinance Institutions Using Guantemalan Data, Managerial Finance, 35(12), 953-974.

Chirkos, A. Y. (2014). Impact of Microfinance on Living Standards, Empowerment and Poverty Alleviation of Poor People in Ethiopia. Research Journal of Finance and Accounting, 5(13), 43-67.

Chowdhury, A. M. R., \& Mosley, P. (2004). The social impact of microfinance. Journal of International Development, 16(3), 2911-300.

Chowdhury, A. (2009). Microfinance as a Poverty Reduction Tool - A Critical Assessment (DESA Working Paper No. 89). Economic \& Social Affairs.

Hermes, N., \& Lensink, R. (2011). Microfinance: Its Impact, Outreach and Sustainability. World 
Development, 39(6), 875-881. https://doi.org/10.1016/j.worlddev.2009.10.021

Hulme, D. (1997). Impact assessment methodologies for microfinance: a review. Paper prepared in conjunction with the AIMS Project for the Virtual Meeting of the CGAP Working Group on Impact Assessment Methodologies.

Hulme, D. (2000). Impact Assessment Methodologies for Microfinance: Theory, Experience and Better Practice. World Development, 28(1), 79-98.

Hussein, M., \& Hussain, S. (2003). The Impact of Micro Finance on Poverty and Gender Equity. Pakistan Gender Report, Pakistan Microfinance Network.

Karlan, D., \& Goldeberg, N. (2007). Impact Evaluation for Microfinance: Review of Methodological Issues (Doing Impact Evaluation Series No. 7). Washington, DC. World Bank.

Khalily, B. (2004). Quantitative approach to impact analysis of microfinance programmes in Bangladesh - What have we learned? Journal of International Development, 16(3), 331-353.

Khandker, S. R. (1998). Fighting Poverty with Microcredit: Experience in Bangladesh. New York, Oxford University Press.

Khandker, S. R., \& Samad, H. A. (2014). Dynamic Effects of Microcredit in Bangladesh. (Policy Research Working Paper No. 6821). World Bank, Washington, DC.

Ledgerwood, J. (1999). Microfinance Handbook: An institutional and Financial Perspective. The World Bank, Washington DC.

Littlefield, E. J., Morduch, J., \& Hashemi, S. (2003). Is Microfinance an Effective Strategy to Reach the Millennium Development Goals [Consultative Group to Assist the Poorest (CGAP) Focus Note Series No. 24]. Washington, DC: CGAP.

Mahajan, V. (2005). From Microcredit to Livelihood Finance. Economic and Political Weekly, 40(41), 4416-4419.

Mamun, A. Al, Malarvizhi, C. A., Hossain, S., \& Tan, S. H. (2012). Examining the Effect of Microcredit on Poverty in Malaysia. Asean Economic Bulletin, 29(1), 15-28. http://doi.org/10.1355/ae29-1b

Mazumder, M. S. U., \& Lu, W. (2015). What Impact Does Microfinance Have on Rural Livelihood? A Comparison of Governmental and Non-Governmental Microfinance Programs in Bangladesh. World Development, 68, 336-354. http://doi.org/10.1016/j.worlddev. 2014.12.002.

Microfinance Barometer. (2018). Microfinance and Profitabilities $\left(9^{\text {th }}\right.$ ed). Paris: Covergences.

Mahmood, T., Arby, M., Hussain, T., \& Sattar, A. (2016). Impact of Microfinance on Income Generation and Living Standards: A Case Study of Dera Ghazi Khan Division, Pakistan Economic and Social Review, 54(1), 73-80.

Matul, M., \& Tsilikounas, C. (2004). Role of microfinance in the household reconstruction process in Bosnia and Herzegovina. Journal of International Development, 16(3), 429-466.

Navajas, S., Schreiner, M., Meyer, R., \& Gonzalez-Vega, C. (2000). Microcredit and the Poorest: Theory and Evidence from Bolivia, World Development, 28(2), 333-346.

Noreen, U., Imran, R., Zaheer, A., \& Saif, M. I. (2011). Impact of microfinance on poverty: A case of Pakistan. World Applied Sciences Journal, 12, 877-883. http://idosi.org/wasj/wasj12(6)/21.pdf

Okibo, B. W., \& Makanga, N. (2014). Effects of micro finance institutions on poverty reduction in Kenya. International Journal of Current Research and Academic Review, 2(2), 76-95.

Onyina, P. A., \& Turnell, S. (2013). The Impacts of a Microfinance Lending Scheme on Clients in Ghana. Accounting \& Taxation, 5(2), 79-89.

Pollin, R., \& Feffer, J. (2007, June 21). Microcredit: False Hopes and Real Possibilities: Is 
microcredit the solution to global poverty? Yes and no... Institute for Policy Studies. https://ips-dc.org/microcredit_false_hopes_and_real_possibilities/

Rifai, A., Goh, S. K., \& Wong, K. N. (2019). Advancing Rural Microfinance Through Local Government: Social Commitment and Financial Sustainability in Riau Province of Indonesia. Journal of Sustainability Science and Management, 14(6), 117-129.

Yuniati. (2014). Pengaruh Pinjaman Dana UED Terhadap Tingkat Kesejahteraan Masyarakat Penerima Pinjaman di Desa Muara Musu Kecamatan Rambah Hilir Kabupaten Rokan Hulu. https://repository.unri.ac.id/handle/123456789/2987

Zeller, M., \& Meyer, R. L. (2002). The Triangle of Microfinance: Financial Sustainability, Outreach and Impact. Food Policy Statement, 40, 1-2. https://core.ac.uk/download/pdf/6289128.pdf 